\title{
Occurrence of Tectona grandis Stem Injury Caused by Cornitermes cumulans Termite
}

\author{
Karyna Lorrainy Silva ${ }^{1}$ (D), Sarah Ladeia ${ }^{1}$ (D), Wezile Nunes ${ }^{1}$ (D), \\ Isabel Carolina de Lima Santos ${ }^{1} \mathbb{D}$, Alexandre dos Santos ${ }^{1}$
}

${ }^{1}$ Instituto Federal de Educação, Ciência e Tecnologia de Mato Grosso - IFMT, Cáceres/MT, Brasil

\begin{abstract}
Termites of the species Cornitermes cumulans (Kollar, 1832) were observed causing injuries in the stem of Tectona grandis in commercial forest plantations in Cáceres, Mato Grosso state, Brazil. C. cumulans forms galleries below the bark, at the heartwood/sap-wood interface of 1.8 years-old trees. This is the first occurrence of this type of injury in stem caused by C. cumulans in T. grandis in Brazil.
\end{abstract}

Keywords: forest entomology, insect pest, teak, initial planting. 
Tectona grandis L.f. (Lamiaceae), known as teak, is origin of Asian occurring naturally in India, Myanmar, Thailand and Laos, because of the characteristics and value of its wood, was introduced in countries of Asia, Africa and America (Hansen et al., 2014). The first seminal forests were planted in Brazil at the 1960s, in Cáceres city, Mato Grosso state (Cruz et al., 2008). There are 87,502 hectares of teak planted in Brazil (IBÁ, 2017) and this area is expanding due to the resistance, durability, and color of the wood, this species is highly demanded in the national market and abroad (Pelissari et al., 2014). The brazilian teak is destined mainly to the civil construction, noble furniture and export (Motta et al., 2013).

T. grandis production may suffer losses at different stages of its development in the field due to insect pests attack (Kulkarni et al., 2009), like any other exotic monoculture in a tropical region (Nascimento et al., 2016). Therefore, the objective of this work was to describe the first occurrence of termites causing injury to T. grandis stem in 1.8 years-old commercial planting.

The 200 hectares of teak planting is in Cáceres ( $16^{\circ} 04^{\prime} 14^{\prime \prime} \mathrm{S}, 57^{\circ} 40^{\prime} 44^{\prime \prime} \mathrm{W}$ and $118 \mathrm{~m}$ altitude), Mato Grosso state, Brazil. The teak stands were planted in December 2015, with $4 \times 4$ meters planting spacing, in a pasture predominant site (Urochloa decumbens). The soil preparation was done with the application of herbicide, plowing, and gradation in total area and subsoiling with fertilization in the planting line. Before planting the seedlings were treated with an insecticide solution based on $0.44 \%$ fipronil (phenyl-pyrazol). After planting, the teak stands were fertilized and kept free of invasive plants.
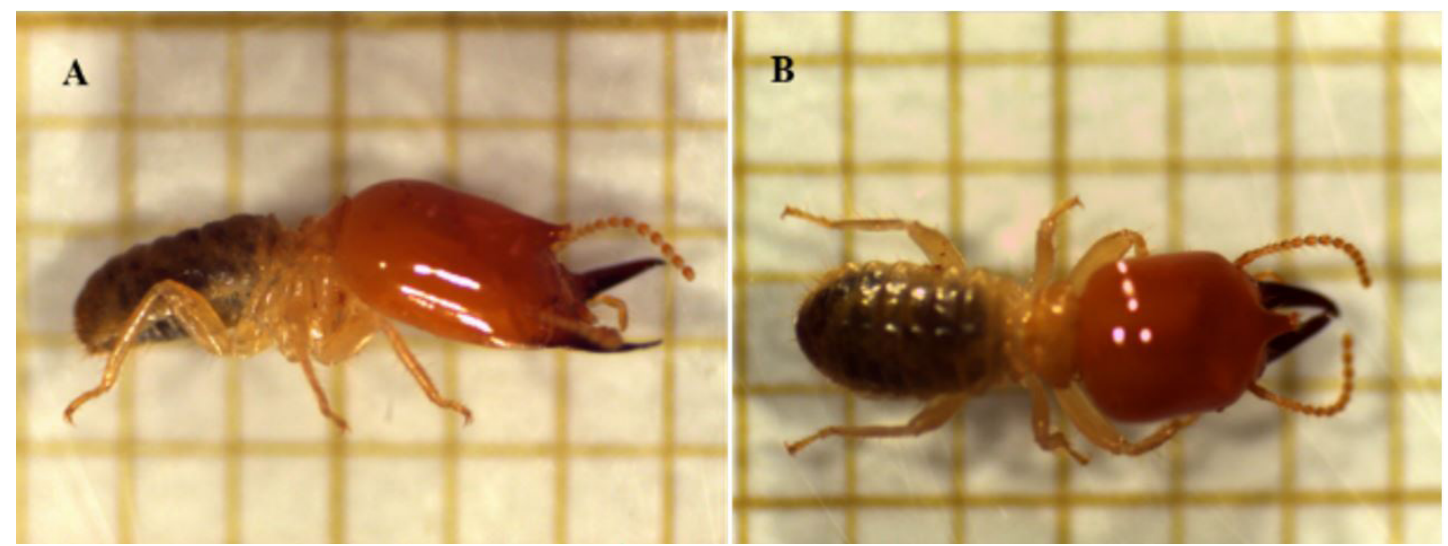

Figure 1. Soldier of Cornitermes cumulans. (A) Side view; (B) Dorsal view.
In May 2018, were observed injuries in the stem region and below the bark of teak trees, caused by termite infestation. The injuries were photographed and measuring, 20 termites of the soldiers caste were collected, kept in recipient containing alcohol $80 \%$ and sent to Laboratório de Fitossanidade (FitLab) of the Instituto Federal de Educação, Ciência e Tecnologia

The termites were observed in the laboratory using a stereoscopic microscope (40x), photographed and identified with the taxonomic keys (Emerson, 1952) and comparison with other specimens already identified. After identification the specimens were deposited in the Reference Collection on Forest Protection of the Laboratório de Fitossanidade of the IFMT - Campus Cáceres.

The termites were identified as Cornitermes cumulans (Kollar, 1832) (Blattodea: Termitidae) (Figure 1).

Infestation of C. cumulans was detected in several trees at different degrees of injury. Initial mounds were found close to the injured plants (Figure 2A), where the presence of clay galleries was observed, located below the bark and at the interface between bark and sap-wood, from the base up to 1.3 meters in tree height (Figure 2B).

The injuries were more pronounced close to the tree base in relation to the rest of the stem (Figure 3A). However, in $50 \%$ of the infested trees, it was observed that the sap-wood was partially consumed by C. cumulans activity (Figure 3B). This part corresponds to the most price value of the tree and the presence of insect de Mato Grosso (IFMT) - Campus Cáceres. 


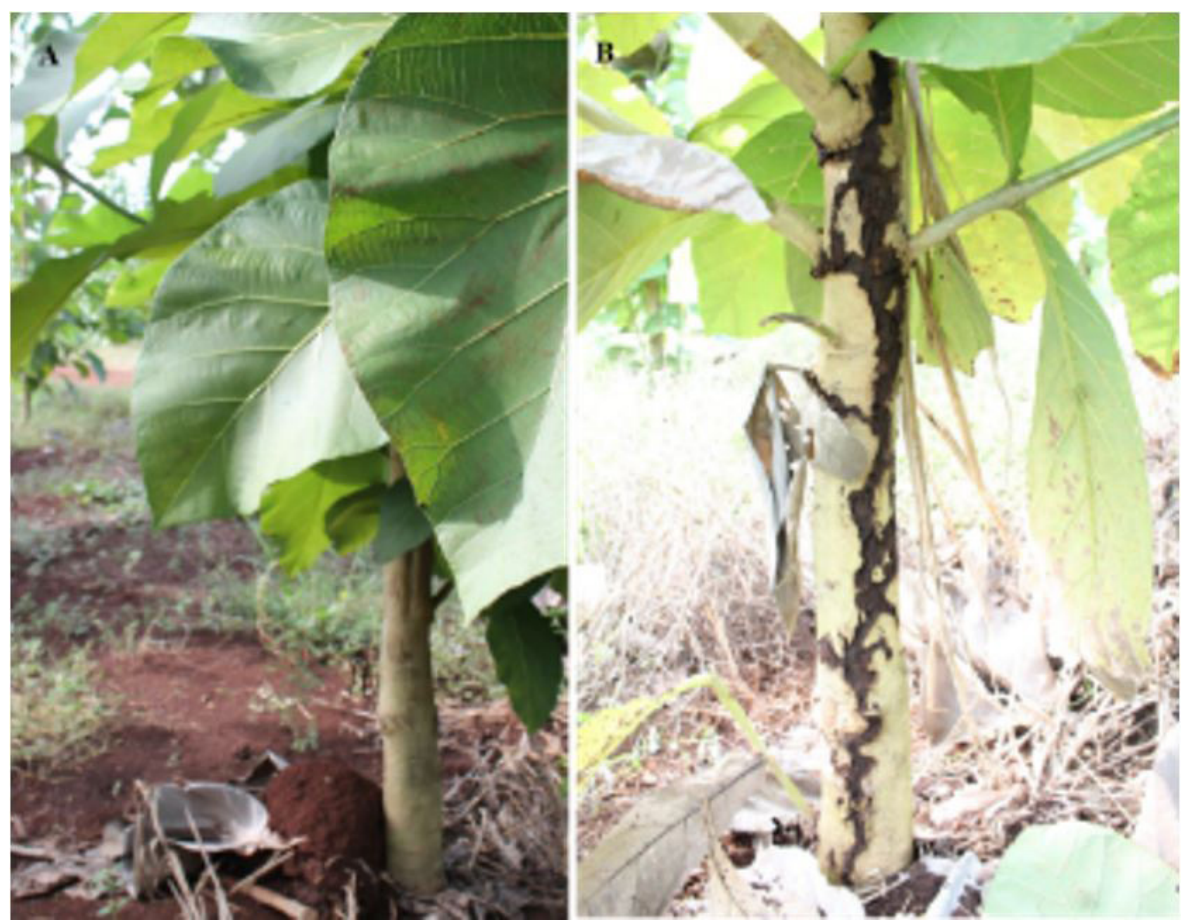

Figure 2. (A) Cornitermes cumulans initial mound near the tree base; (B) C. cumulans clay galleries in teak stem up to $1.3 \mathrm{~m}$ above ground.

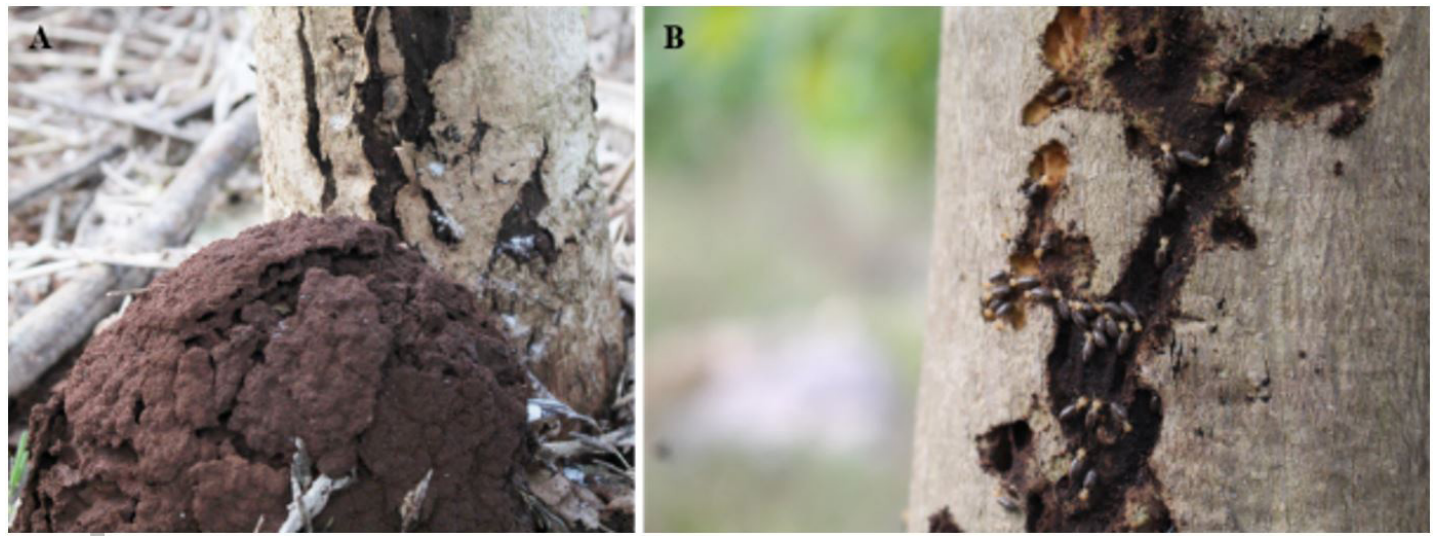

Figure 3. (A) Tree base with presence of galleries in the bark/sap-wood interface; (B) Galleries and consumption of sap-wood by C. cumulans in teak stem.

galleries generate losses and harm the wood export (Abreu et al., 2002).

C. cumulans is a termite species that produces mound-shaped nests, where it has an underground and a superficial structure (larger and visible portion) (Redford, 1984). This species of termite normally causes direct losses in the young phase of the forest plantations, and can cause mortality of the seedlings, as it causes destruction of the root system of the plants and, indirectly, compromises the development of the trees, making them more susceptible to the attack of other pests (Junqueira et al., 2009; Leitão-Lima et al., 2013).

They are commonly found in pasture areas, because of the large amount of food available as dry matter (Czepak et al., 2003; Carrijo et al., 2009; Cunha \& Morais, 2010), although they also feed on dead leaves and roots (Junqueira et al., 2008). Due to the ecological no balance generated by the anthropic action in the 
preparation of areas for planting, this insect presents a potential risk of pest to forest plantations (Lima \& Costa-Leonardo, 2007).

In the absence of preferable food, termites seek alternatives by selection pressure, since normally in forest species the food preference is by plant roots in the seedling phase (Junqueira et al., 2008; Leitão-Lima et al., 2014). Since teak has a considerable and expanding area in the country, high value and great demand in the foreign and domestic market, it is necessary to seek strategies of management and preventive control of this insect, in order that this species does not cause economic damages to the enterprises forests.

There is no product registered to control C. cumulans in teak plantations. However, to chemically control this termite species in other crops, the perforation of the mound with an steel bar of a maximum of $1 \mathrm{~cm}$ in diameter is carried out directly in the nests until it reaches the cellulose chamber and one liter of insecticidal syrup based on fipronil, with $0.1 \mathrm{~g}$ of the active ingredient per termite nest, by means of a hose coupled to a funnel or using the coastal pump without the nozzle. (Canesin et al., 2012). To combat C. cumulans termites, the process should be done 30 to 60 days before soil preparation, to eliminate them from the area to be planted and to avoid breeding by fragmentation of the nests (Canesin et al., 2012).

In the sugarcane industry, attractive cardboard traps impregnated with $0.1 \mathrm{~g}$ of entomopathogenic fungi conidia Beauveria bassiana and/or Metarhizium anisopliae or their association with the insecticide fipronil $0.003 \%$ are used to control C. cumulans (Almeida et al., 2000; Chakraborti, 2017). This technique consists in maximizing the action of the entomopathogenic fungus on the termite population contaminated with an insecticide at the sub-lethal dose, while the workers feed on the cardboard trap (Almeida et al., 2000).

This paper reports for the first time a new stem injury caused by C. cumulans termite in teak plantations in Brazil.

\section{SUBMISSION STATUS}

Received: 10 aug., 2018

Accepted: 24 nov., 2018

\section{CORRESPONDENCE TO}

\author{
Alexandre dos Santos \\ Instituto Federal de Educação, Ciência e \\ Tecnologia de Mato Grosso - IFMT, Avenida \\ dos Ramires, s/n, Distrito Industrial, CP 244, \\ CEP 78200-000, Cáceres, MT, Brasil \\ e-mail: alexandre.santos@cas.ifmt.edu.br
}

\section{REFERENCES}

Abreu RLS, Sales-Campos C, Hanada RE, Vasconcellos FJ, Freitas JA. Avaliação de danos por insetos em toras estocadas em indústrias madeireiras de Manaus, Amazonas, Brasil. Revista Árvore 2002; 26(6): 789-796. http://dx.doi. org/10.1590/S0100-67622002000600015.

Almeida JEM, Alves SB, Almeida LC. Controle de Heterotermes tenuis (Hagen) (Isoptera: Rhinotermitidae) e Cornitermes cumulans (Kollar) (Isoptera: Termitidae) com inseticida fipronil associado ao fungo entomopatogênico Beauveria bassiana (Bals.) Vuill. em isca atrativa na cultura da cana-de-açúcar (Saccharum officinarum L.). Arquivos do Instituto Biológico 2000; 67(2): 235-241.

Canesin A, Degrande PE, Crispim BA, Tannous LC, Faccenda O. Eficiência de formulações granuladas e líquidas de inseticidas para cupim de montículo Cornitermes cumulans (Kollar) (Isoptera: termitidae). BioAssay 2012; 7(8): 1-5. http://dx.doi.org/10.14295/BA.v7.0.76.

Carrijo TF, Brandão D, Oliveira DE, Costa DA, Santos T. Effects of pasture implantation on the termite (Isoptera) fauna in the Central Brazilian Savanna (Cerrado). Journal of Insect Conservation 2009; 13(6): 575-581. http://dx.doi. org/10.1007/s10841-008-9205-y.

Chakraborti S. Assessing effectiveness of an alternate management system for termites in sugarcane plantation. Journal of Entomological Research 2017; 41(1): 45-49. http:// dx.doi.org/10.5958/0974-4576.2017.00008.1.

Cruz JP, Leite HG, Soares CPB, Campos JCC, Smit L, Nogueira GS et al. Modelos de crescimento e produção para plantios comerciais jovens de Tectona grandis em Tangará da Serra, Mato Grosso. Revista Árvore 2008; 32(5): 821-828. http://dx.doi.org/10.1590/S0100-67622008000500006.

Cunha HF, Morais PPAM. Relação espécie-área em cupinzeiros de pastagem, Goiânia-GO, Brasil. EntomoBrasilis 2010; 3(3): 60-63. http://dx.doi.org/10.12741/ebrasilis.v3i3.102.

Czepak C, Araújo EA, Fernandes PM. Ocorrência de espécies de cupins de montículo em pastagens no Estado de Goiás. Pesquisa Agropecuária Tropical 2003; 33(1): 35-38.

Emerson AE. The neotropical genera Procornitermes and Cornitermes (Isoptera, Termitidae). Bulletin of the American Museum of Natural History 1952; 99: 479-539.

Hansen OK, Changtragoon S, Ponoy B, Kjær ED, Minn Y, Finkeldey R et al. Genetic resources of teak (Tectona 
grandis Linn. f.) strong genetic structure among natural populations. Tree Genetics \& Genomes 2014; 11(1): 1-16.

Indústria Brasileira de Árvores - IBÁ. Relatório anual 2017: ano base 2016. Brasília: IBÁ; 2017.

Junqueira LK, Diehl E, Berti E Fo. Termites in eucalyptus forest plantations and forest remnants: an ecological approach. Bioikos 2008; 22(1): 3-14.

Junqueira LK, Diehl E, Berti E Fo. Termite (Isoptera) diversity in eucalyptus-growth areas. Sociobiology 2009; 53(3): 805-828.

Kulkarni N, Paunikar S, Joshi KC, Rogers J. White grubs, Holotrichia rustica and Holotrichia mucida (Coleoptera: Scarabaeidae) as pests of teak (Tectona grandis L. f.) seedlings. Insect Science 2009; 16(6): 519-525. http:// dx.doi.org/10.1111/j.1744-7917.2009.01289.x.

Leitão-Lima PS, Lima EV, Wilcken CF. Danos de Cornitermes cumulans Kollar, 1832 (Isoptera: Termitidae) em mudas de Eucalyptus grandis $\mathrm{x}$ Eucalyptus urophylla. Revista de Agricultura 2013; 88(2): 152-161.

Leitão-Lima PS, Lima EV, Wilcken CF, Pereira LG. Atração de Cornitermes cumulans Kollar, 1932 (Isoptera: Termitidae) à raiz de eucalipto e ao substrato para produção das mudas. Revista de Agricultura 2014; 89(3): 187-198.
Lima JT, Costa-Leonardo AM. Recursos alimentares explorados pelos cupins (Insecta: isoptera). Biota Neotropica 2007; 7(2): 243-250. http://dx.doi.org/10.1590/S167606032007000200027.

Motta JP, Oliveira JTS, Paes JB, Alves RC, Dambroz GBV. Resistência natural da madeira de Tectona grandis em ensaio de laboratório. Ciência Rural 2013; 43(8): 1393-1398. http://dx.doi.org/10.1590/S0103-84782013005000097.

Nascimento DA, Anunciação RM Jr, Arnhold A, Ferraz AC Fo, Santos A, Zanuncio JC. Expert system for identification of economically important insect pests in commercial teak plantations. Computers and Electronics in Agriculture 2016; 121: 368-373. http://dx.doi.org/10.1016/j. compag.2015.12.024.

Pelissari AL, Guimarães PP, Behling A, Ebling AA. Cultivo da teca: características da espécie para implantação e condução de povoamentos florestais. Agrarian Academy 2014; 1(1): 127-145. http://dx.doi.org/10.18677/Agrarian_ Academy_2014_011.

Redford KH. The termitaria of Cornitermes cumulans (Isoptera, Termitidae) and their role in determining a potential keystone species. Biotropica 1984; 16(2): 112119. http://dx.doi.org/10.2307/2387842. 